\title{
Comparative Study of Relation between Laxative and Emmenagogue Activity of Herbs Described in Gunapadam Mooligai
}

\author{
Packia Sri $D^{1}$, Kingsly $A^{2}$ \\ ${ }^{1}$ PG Scholar, ${ }^{2}$ Reader and Head of the Department, \\ Department of Gunapadam, Government Medical College, Palayamkottai, Tamil Nadu. \\ Corresponding Author: Packia Sri D
}

\begin{abstract}
Introduction: According to siddha system of medicine 10 vayu and 10 nadis are mainly consider for curing and producing disease among 10 vayu $2^{\text {nd }}$ vayu known as abhana vayu action on laxative and emmenagogue herbs are described.

Aim: To compare the relationship between laxative and emmenagogue activities of herbal drug prescribed in Gunapadam Molligal book.

Method: A comparative study of relation between laxative and emmenogogue activity was done in herbs described in Gunapadam mooligai book. In the book the author has described 1535 herbs and their activity and they are co related

Conclusion: Out of 40 herbs of emmenogogue activity 26 herbs having laxative activity in which 17 are laxative and 8 herbs are cathartic activity. Most of the drug with emmenogogue activity also having laxative activity. As the result emmenogogue activity of herbs are given along with laxative activity. The normal function of ABHANA VAYU will help in the normal function of uterur, urinary system and large intestine function.
\end{abstract}

Keywords: laxative, emmenagogue, siddha herb

\section{INTRODUCTION}

As per the siddha system of medicine is based on the panja putham and 96 thathuvam. It is considering that our body is also made up of panjaputham and 96 thathuvam. Among them most used sign's in siddha system is 3 vital houmours (vatham, pitham, kabam) and 10 nadi's and 10 vayu's.

We are treating the diseases based on their nadi, vayu and by affected vital houmours. it's said that increased or decreased of vital signs cause disease in human body.

Among 10 vayu's $2^{\text {nd }}$ vayu known as ABHANA VAYU. It has a action of sending urine, faeces, sperm and ovum out from the body regularly. Increase and decrease in this abhana vayu cause diseases like constipation, pcos, amennorhae, and burning urination, etc,...

\section{Mordern Aspect: \\ Laxative activity:}

Laxative herbs that in some way stimulate the bowel to promote bowel movements. The action is called by numbers of different names depending on the strength and usually their strengths considered to be dose dependent with the move stimulating laxatives containing higher level of anthroquniones in the order they are

$>$ laxative

$>$ purgative

$>$ aperients 
Packia Sri D et.al. Comparative study of relation between laxative and emmenagogue activity of herbs described in gunapadam mooligai.

\section{EMMENOGOGUE ACTIVITY:}

Emmenogogue activities are the herbs which stimulate blood flow in the pelvic area and uterus some stimulate menstruation. Women's use emmenogogue to stimulate menstruation flow when the menstruation is absent for a reason other than pregnancy such as hormonal disorder or conditions like oligomenorrhea.

\section{METHOD}

A comparative study of relation between laxative and emmenogogue activity was done in herbs described in Gunapadam mooligai book. In the book the author has described 1535 herbs and their activity and they are co related
The emmenogogue and laxative activity of herbs are tabulated and the results are calculated.

\section{ABHANA DECRESED}

CONSTIPATION AMENNORHOEA

LAXATIVE

Emmenagogue<smiles>C1CCCCC1</smiles>

ABHANA VAYU INCRASED<smiles>C1CCCCC1</smiles>

DISEASE CURE

\begin{tabular}{|c|c|c|c|c|}
\hline $\begin{array}{l}\text { S. } \\
\text { NO }\end{array}$ & NAME OF HERB & $\begin{array}{l}\text { LAXATIVE } \\
\text { ACTIVITY }\end{array}$ & $\begin{array}{l}\text { CATHARTIC } \\
\text { ACTIVITY }\end{array}$ & EMMENOGOGUE \\
\hline 1 & Aarasu(FICUS RELIGIOSA) & PRESENT & & PRESENT \\
\hline 2 & ARUVATHA(RUTA CHALPENSIS) & & & PRESENT \\
\hline 3 & $\begin{array}{l}\text { ADU } \quad \text { THINNAPALAI } \\
\text { BRACTEOLATA) }\end{array}$ & PRESENT & & PRESENT \\
\hline 4 & ALIVERAI(LEPIDIUM SATIVUM) & PRESENT & & PRESENT \\
\hline 5 & ARTU TUMATTI(CITULLUS CLCOCYANTHIS) & PRESENT & & PRESENT \\
\hline 6 & ECHCHURA MULI(ARISTOLOCHIA INDICA) & & & PRESENT \\
\hline 7 & ETTI(STRYCHNOS NUX VOMICA) & & PRESENT & PRESENT \\
\hline 8 & ELL(SESAMUM INDICUM) & PRESENT & & PRESENT \\
\hline 9 & KUROSANI OMAM(HYOSCYAMUS NIGER) & & & PRESENT \\
\hline 10 & KADALAI(CICER ARIETINUM) & PRESENT & & PRESENT \\
\hline 11 & KATUKUROHANI(HELLEBOROUS NIGER) & & PRESENT & PRESENT \\
\hline 12 & KALIYANA PUSANIKKAY(BENINCASA HISPIDA) & PRESENT & & PRESENT \\
\hline 13 & KAZHARCHI KODI(CESALPINIA BONDUC) & & & PRESENT \\
\hline 14 & KATRAZHAI(ALOE BARBADENSIS) & & PRESENT & PRESENT \\
\hline 15 & KARIABOLAM(ALOE LITTORALIS) & PRESENT & PRESENT & PRESENT \\
\hline 16 & KATTU KADUGU(CLEOME VISCOSA) & PRESENT & & PRESENT \\
\hline 17 & KATTU MULLANGI(BIUMEA LACERA) & & & PRESENT \\
\hline 18 & KATTU VENGAYAM(URGINEA INDICA) & & & PRESENT \\
\hline 19 & KUNKUMAPPU(CROCUS SATIVUS) & & & PRESENT \\
\hline 20 & KUNTHIRIKKAM(BOSWELLIA SERRATA) & & & PRESENT \\
\hline 21 & KUPPAI MENI(ACALYPHA INDICA) & & PRESENT & PRESENT \\
\hline 22 & KURUVER(VETIVERIA ZIZANIOIDES) & & & PRESENT \\
\hline 23 & KORAI(CYPERUS ROTANDUS) & & & PRESENT \\
\hline 24 & CHANAPPU(CROTALARIA JUNCEA) & & PRESENT & PRESENT \\
\hline 25 & SHANBAGAM(MICHELIA CHAMPACA) & & PRESENT & PRESENT \\
\hline 26 & CHATHA KUPPAI(ANETHUM GRAVEOLENS) & PRESENT & & PRESENT \\
\hline 27 & SATTICHCHARANAI (TRIANTHEMA DECANDRA) & PRESENT & & PRESENT \\
\hline 28 & KAURUNJCHERAKAM(NIGELLA SATIVA) & & & PRESENT \\
\hline 29 & CHEMPARATTAI(HIBISCUS ROSA SINENSIS) & PRESENT & & PRESENT \\
\hline 30 & CHEMPAI(SESBANIA SESBAN) & & & PRESENT \\
\hline 31 & THARA(FUMARIA PERVIFLORA) & PRESENT & & PRESENT \\
\hline 32 & THUMBAI(LEUCAS ASPERA) & PRESENT & & PRESENT \\
\hline 33 & NUNA(MORINDA TINCTORIA) & & & PRESENT \\
\hline 34 & PAPPALI(CARICA PAPAYA) & PRESENT & & PRESENT \\
\hline 35 & PARUTTI(GOSSYPIUM HERBACEUM) & & & PRESENT \\
\hline 36 & PUNGU(PONGAMIA PINNATA) & PRESENT & & PRESENT \\
\hline 37 & PERUNGAYAM(FERULA ASAFOEDIA) & PRESENT & & PRESENT \\
\hline 38 & MACHIPACHAI(ARTEMISIA NILAGIRICA) & & & PRESENT \\
\hline 39 & MILAKAI(CAPSICUM ANNUM) & & & PRESENT \\
\hline 40 & MALAI VEMBU(MELIA AZEDARACH) & & PRESENT & PRESENT \\
\hline
\end{tabular}


Packia Sri D et.al. Comparative study of relation between laxative and emmenagogue activity of herbs described in gunapadam mooligai.

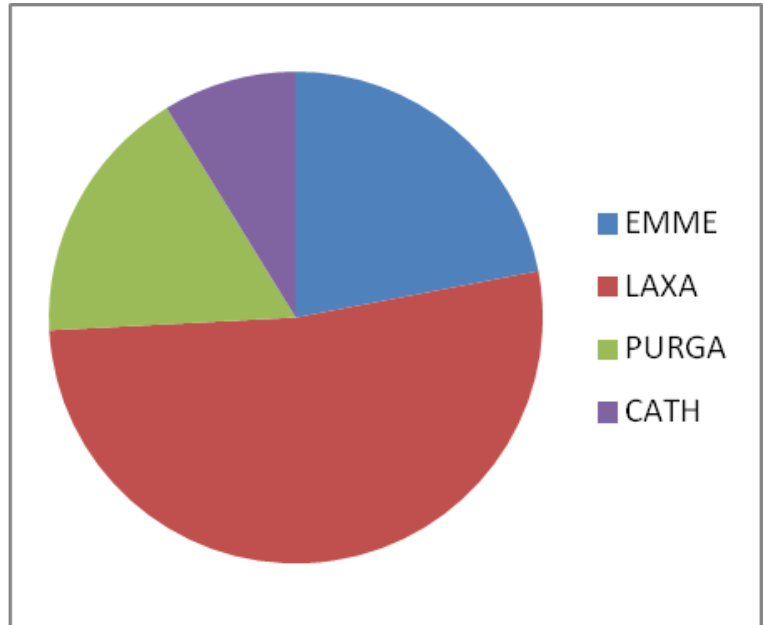

PIE CHART 1: Pie chart for emmenogogue and laxative and cathartic herbs:

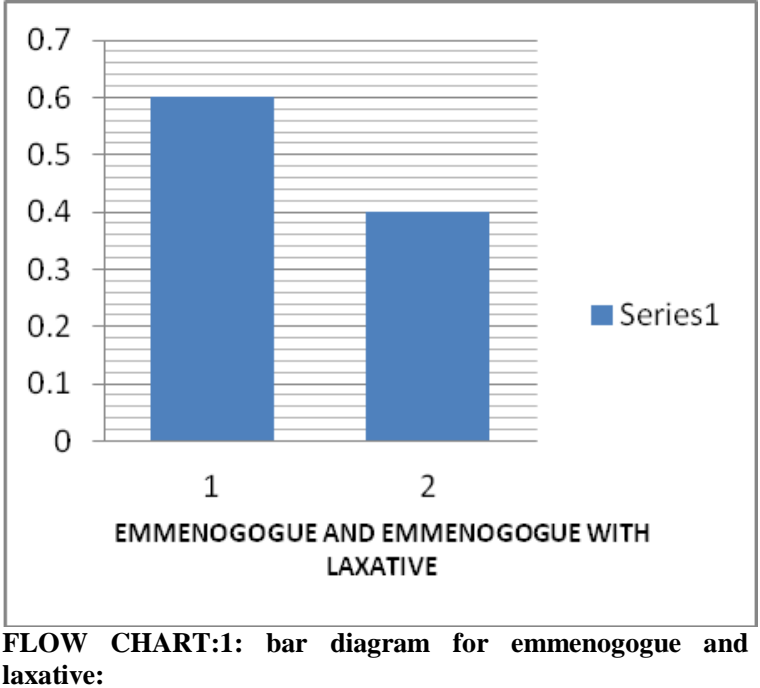

laxative:

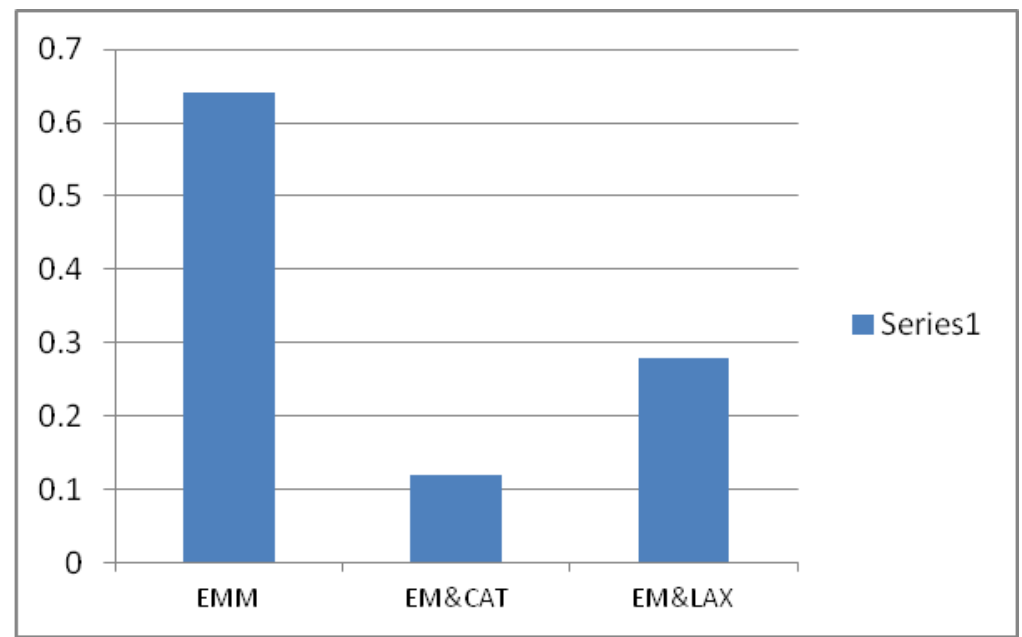

FLOW CHART:2: Bar diagram for relation between emm, emm with laxa and emm with cat

\section{CONCLUSION}

As per the literature 1535 herb described in Gunapadam book by author murugaesha mudaliar. There are 40 herbs for emmenogogue activity, 95 herbs for laxative activity, 31 herbs containing purgative activity, and 16 herbs containing cathartic activity

Out of 40 herbs of emmenogogue activity 26 herbs having laxative activity in which 17 are laxative and 8 herbs are cathartic activity. Most of the drug with emmenogogue activity also having laxative activity.

As the result emmenogogue activity of herbs are given along with laxative activity. The normal function of ABHANA VAYU will help in the normal function of uterur, urinary system and large intestine function.
Acknowledgement: None

\section{Conflict of Interest: None}

\section{Source of Funding: None}

\section{REFERENCES}

1. Vaidhyarathinam Murugesa Mudhaliyar. Gunapadam porut pantu nool mooligai vaguppu II edition. Department of Indian Medicine and Homeopathy, Chennai-106 2001

2. Dr.K.M Nadkarni's Indian Materia Medica, Vol 1, Bombay Popular Prakashan.

3. R. Devi, M. Subhathra, V.Phuranee, L. Ponnkuzhali, M.Thivya, S. Victoria(2017). A review article on Medical Herbs in Siddha Medicine for 
Packia Sri D et.al. Comparative study of relation between laxative and emmenagogue activity of herbs described in gunapadam mooligai.

Gynecological disorder Int, J.Curr.Res Chem. Pharm Sci 4(6):58-66

4. Sambasivam Pillai Tv. Dictionary Tamil to English Vol-II. I edition, Chennai, The Research Institute of Siddha Science: 1992

5. Bhattacharjee SK Hande Book of Medical Plant Pointer Pub. Jaipur 1998, $1-6$
How to cite this article: Packia Sri D, Kingsly A. Comparative study of relation between laxative and emmenagogue activity of herbs described in gunapadam mooligai. Int J Health Sci Res. 2021; 11(5):136-139. DOI: $\quad$ https://doi.org/10.52403/ijhsr.

$* * * * * *$ 